\title{
MODELLING THE GROWTH OF YOUNG INDIVIDUALS OF PINUS NIGRA ON THIN CARBONATE SOILS UNDER CLIMATE CHANGE IN HUNGARY
}

\author{
A. Trájer ${ }^{1,2 *}$, Á. Bede-Fazekas ${ }^{3}$, T. HAmmer ${ }^{1}$ and J. Padisák $K^{1,2}$ \\ ${ }^{1}$ Department of Limnology, University of Pannonia, H-8200 Veszprém, Egyetem utca 10, \\ Hungary; ${ }^{*}$ E-mail: atrajer@gmail.com \\ ${ }^{2}$ MTA-PE Limnoecology Research Group, H-8200 Veszprém, Egyetem utca 10, Hungary \\ ${ }^{3}$ Department of Garden and Open Space Design, Faculty of Landscape Architecture \\ Corvinus University of Budapest, H-1118 Budapest, Villányi út 29-43, Hungary
}

(Received 3 November, 2014; Accepted 15 December, 2014)

\begin{abstract}
Climate change highly impacts on tree growth and also threatens the forest of the karstic terrains. From the 1980s the frequency of decay events of the Pinus nigra Arnold forests showed a marked increase in Hungary. To understanding the vulnerability of Pinus nigra forests to climate change on shallow karstic soils in continental-sub Mediterranean climatic conditions we developed the study of three sampled population in the typical karstic landscape of Veszprém in North Transdanubia. We built our model on non-invasive approach using the annual growth of the individuals. MPI Echam5 climate model and as aridity index the Thornthwaite Agrometeorological Index were used. Our results indicate that soil thickness up to $11 \mathrm{~cm}$ has a major influence on the main growth intensity, however, aridity determines the annual growth rate. Our model results showed that the increasing decay frequency in the last decades was a parallel change to the decreasing growth rate of pines. The climate model predicts the similar, increased decay frequency to the presents. Our results can be valid for a wider areas of the periphery of Mediterranean climate zone while the annual-growth based model is a cost-effective and simple method to study the vitality of pine trees in a given area.
\end{abstract}

Key words: climate change, Pinus nigra, soil depth, Thornthwaite Agrometeorological Index aridity

\section{INTRODUCTION}

The species of Pinus genus are good climate indicators within the ligneous plants (Ferrio and Voltas 2005, Gagen et al. 2004). In the 19th and 20th centuries the afforestation of the dry, karst areas were attempted by the plantation of the Pinus nigra Arnold. By the end of the 20th century in the dolomite grasslands of the Hungarian Central Range P. nigra become the dominant sce- 
nic element of the landscape in contrast with the edge position of the natural distribution of black pine. Although pines have an important role in the conservation and the reestablishment of the thin soil layer in karren landscapes (Veress 2010) the extensive plantation of Pinus nigra caused the degradation of the dolomite grassland flora and fauna (Csontos et al. 1996). In addition, $P$. nigra stands are subjected to an increased risk of fire, especially in age class 61-80 years in Hungary (Cseresnyés et al. 2006). However, P. nigra is a drought tolerant tree; the development of the annual rings is noticeably affected by drought (Linares and Tíscar 2010, Martín-Benito et al. 2008). The "pine afforestation programme", was particularly active between the 1960s and 1980s in Hungary, although from the middle of the 1980s new or unknown diseases appeared on the trees causing the mass death of the plantations about four times in these period in Transdanubia (Koltay 2001a). The earliest needle blight case was observed in the Mecsek Mts, SW Hungary in 1948. Also severe mass of deaths were observed in the Mecsek Mts in 1948, 1962 and 1980, in the Bakony Mts (Transdanubian Mountain Range) in 1960 and 1962, in the Gödöllö Hills in 1960 and 1962 (Lengyel 1964). The infection of the pines with Cenangium ferruginosum Fr. also had important role since Cenangium typically attacks the weakened trees (Koltay et al. 2005). The opportunist Sphaeropsis sapinea (Fr.) Dyko et B. Sutton also an important and frequent cause of the death of pines (Blodgett and Stanosz 1997). Dothistroma septosporum (Dorog.) M. Morelet and Dothistroma pini Hulbary also frequently cause serious pine needle disease (Barnes et al. 2011, Koltay 1998, 2001b, Koltay et al. 2005). Further deforestation episodes occurred in the 1990s (Koltay 1997) and the latest during the severe and prolonged aridity period of 2011-2012, particularly in the Keszthely Mts, where a major forest decay has already been observed in the 2000s (Csillag 2006), and e.g. in Mátrafüred, Northern Hungary (Janik et al. 2012) and in 2013 in the Mecsek Mts (Szilasi 2013). Although fungal infections in many cases were observed, Lengyel suggested already in 1964, that in addition the opportunist fungal infections climatic factors may have to play key role in the forest decays (Lengyel 1964). This is all the more remarkable since the concept of climate change was not known in the recent sense in the 1960s. Koltay (1994) also claimed for the causality of the environment factors. According to different regional climate models about 3.8-3.9 ${ }^{\circ} \mathrm{C}(\mathrm{B} 2)$ or $4.8^{\circ} \mathrm{C}$ (A2) summer warming trends are expected in the studied area. Although the expected change of annual total precipitation is not significant, the restructuration of the distribution of the annual precipitation is very likely, while it is expected to decrease in summer and increase in winter, which means the reversal of the recent precipitation seasonality. However, the increasing temperatures may extend the growing season and provide the photosynthesis (Wullschleger et al. 2002), water availability will restrict the productivity of $P$. 
nigra (Loustau et al. 2005, Martínez-Vilalta et al. 2008). Precipitation variability could be important since extreme events as severe droughts, could have drastic consequences on tree growth and survival (Granier et al. 2007, Loustau et al. 2005). The increasing evapotranspiration can result the decrease of the soil moisture in the growing season (Linares et al. 2009, Sabaté et al. 2002), which can be severe in thin soils. The aridity and soil-dependence of the survival and growing of the young pine individuals determine the success of the whole plantation. The previous studies about the climate-sensitivity of $P$. nig$r a$ mainly were based on the invasive examination of the rings of adult trees. Young trees usually have longer growing season and respond faster (Vieira et al. 2009), the relationships between climatic events and the annual growth established by the examination of older tree rings cannot be used directly for the young stands. Examination of the tree rings in case of young ones does not allow the detection of the short-term meteorological events as short, but severe droughts which form a very important part of the results of climate change.

Aims - In this paper, we investigate the effect of the soil depth on dolomite karst, the subregional aridity trends and the proposed climate change in the young individuals of Pinus nigra. Our specific aims were: (1) to describe temporal patterns of temperature and precipitation on the annual vertical growth of young $P$. nigra individuals, (2) to quantify the aridity-annual growing and aridity-presence relationship of $P$. nigra in its distribution range; and (3) to explain the fact why the plantation of black pine have achieved good results in the past five decades in Hungary. We hypothesise that soil thickness and the aridity in the growing period may have great influence on the annual offshoot's values. Our aim was to examine whether the xeric climate conditions caused the forest decay (4) that how can explain the changing climatic suitability the decreasing extent and the decay of the P. nigra forests in Hungary (Fig. 1; KSH). According to Koltay (2001a) major forest decays occurred in 1946-1948, 1960-1962, 1987, 1992-1993, 1993-1996, 1996-1998, 1999-2001, 2005-2006, 2009-2010 and 2012, when in the 1950s and 1970s major decays were not registered in Hungary.

\section{MATERIALS AND METHODS}

The site of the study - The study was performed in the central part of the Transdanubian Central Range in Hungary. The bulk of the Balaton Highlands which is the part of the Transdanubian Central Range is built up mainly of Triassic limestone and dolomite (Haas 2002, Haas and Demény 2002). The Triassic carbonates were deposited in a shallow marine environment in the western protrusion of the Tethys Ocean (Balog et al. 1997). The landscape was strongly affected by repeated, four or five phases of tectonic movements, 

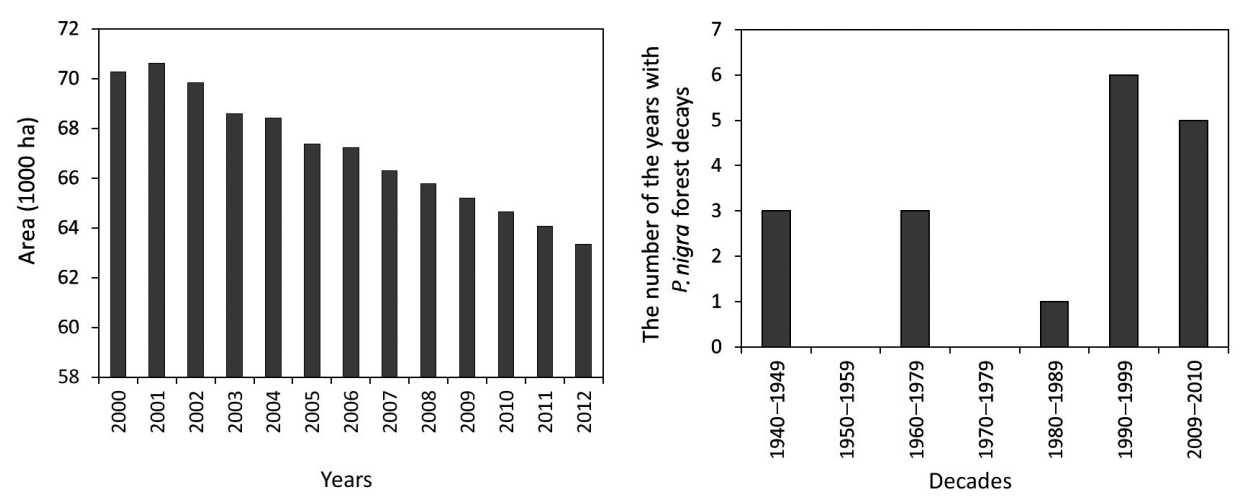

Fig. 1. The decrease of the forested areas with Pinus nigra in Hungary (left, source: KSH) and the number of the Pinus nigra forest decays in the decades between 1940 and 2010 in Hungary (right) according to Koltay (2001a)

counterclockwise rotation and brittle deformation, which resulted the fragmentation material (Balla 1988, Márton and Fodor 2003). The studied karst plateau is characterised by low hills and erosion valleys and a major fault (Fig. 2, left) border to the north the plate-like terrain (Fig. 2, right).

A total of 205 individual were involved in the study. Four sites were selected near Veszprém (Hungary): two plantations of them, Site-1 and Site-2 $(\mathrm{n}=81$; Fig. 3), the plantations were planted in 2008 with about $10 \mathrm{~cm}$ high seedlings. In Site-1 and Site-2: 1) the soil depth around the individuals, 2) the corresponding crown width, 3) the trunk diameter at the soil level and 4) the heights of the individuals from the soil level to the top of the trunk without the needles were measured. Site- 3 contained different aged individuals $(\mathrm{n}=$ 124) between the ages of 4 to 12 years (Fig. 2). In this site only the annual segment length of the individuals were measured. The environment of Site-3 was similar to the Site-1 and Site-2. The measurements were executed in January
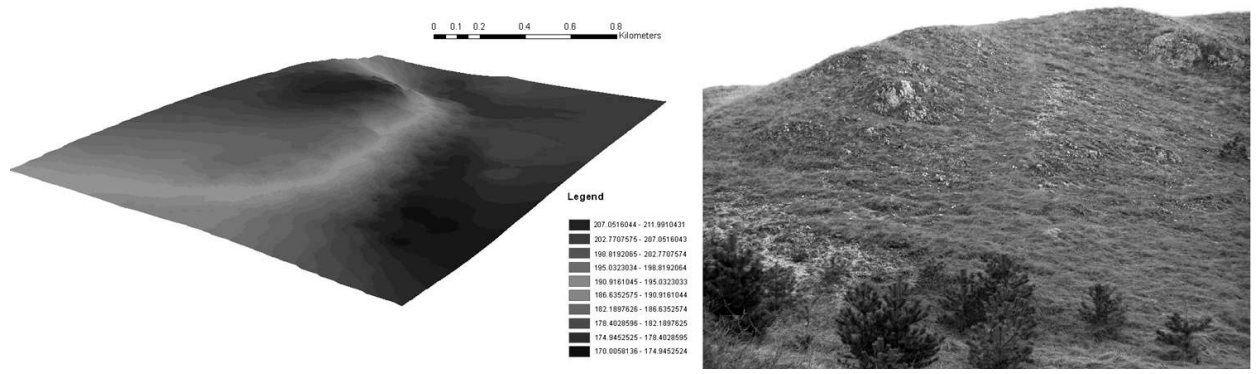

Fig. 2. Three-dimensional terrain model (left picture) and a characteristic topography and landscape of the characteristic part of the karst plateau with Pinus nigra individuals in the foreground near to the studied place (right picture) 
to March of 2014 before the annual growing season. We selected the different aged young population of Site-3 to gain valid data about the correlation of the relative annual growth rate of the individuals and a monthly aridity index from a heterogenic group. In contrast, the same aged plantations of Site-1 and Site-2 provided us the ability to analyse the influence of the soil depth on growth in a same aged, homogenous group. Since the age heterogeneity of the Site- 3 this population was used as the subject of determination of the correlation between the annual growth and aridity, while in case of Site- 1 and Site-2 due to the same age of the individuals of this site were involved in the analysis of the influence of the soil thickness on growth. It is important to note that the ecological patterns in the studied sites as the material of the bedrock (Triassic Budaörs Dolomite Formation in Site-1 and Site-2, Triassic Main Dolomite Formation in Site-3), the soil thickness and composition (calcareous skeletal soils with soil thickness of 0 to $11 \mathrm{~cm}$ ), the elevation above sea level (211-212 $\mathrm{m}$ in Site-1, 208-210 $\mathrm{m}$ in Site-2 and 218-222 $\mathrm{m}$ in Site-3) were quite similar in sites.

Measuring soil thickness and morphometric features - Due to the tectonic history, carbonate and dolomite rubble-rich skeletal soils are characteristic to the area (Fig. 4, left). The bedrock of the thin soils is hard, cemented dolomite and limestone breccia. The thickness of the thin, dolomite bedrock soil under the pine individuals were estimated by averaging of four manual, perpendicular soil sounding measurements with an iron sounder from $30 \mathrm{~cm}$ of the basis of the trunks in each case (Fig. 4, right). The thickness of the soil was defined by the depths, where the probe reached the firm bedrock. The soil thickness data were averaged in each case. Each of the studied individuals grows on well-lit,
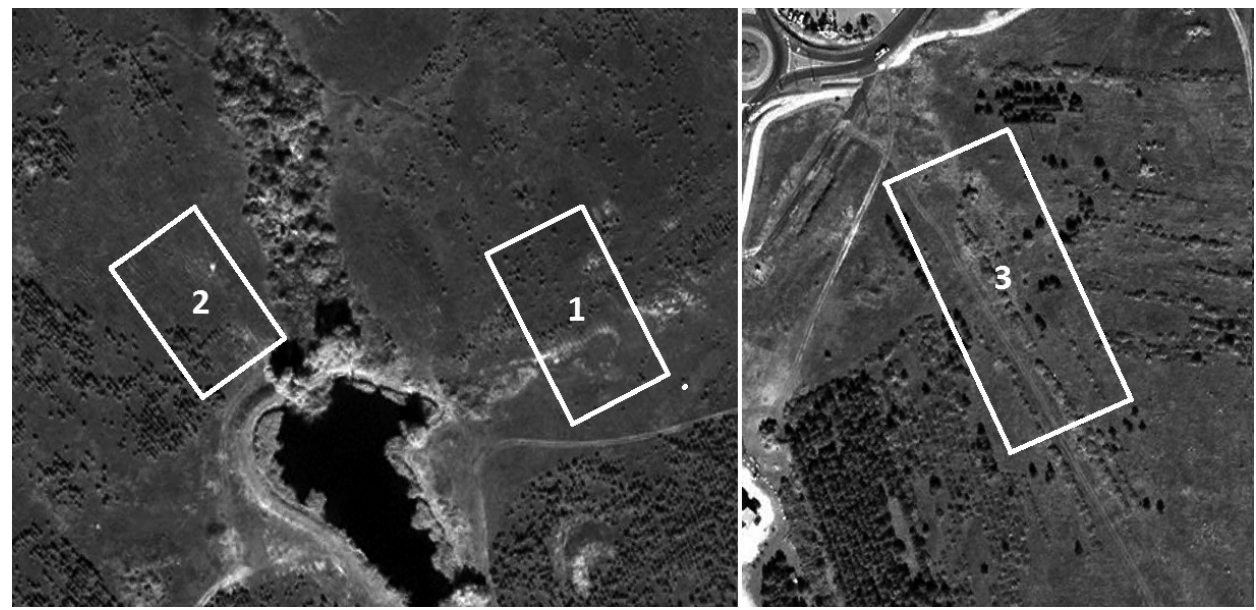

Fig. 3. The false-colored satellite-image (by $800 \%$ colour oversaturation) of the studied

P. nigra plantations (Site-1, -2, -3). Oversaturation was made by Adobe Photoshop CS4 

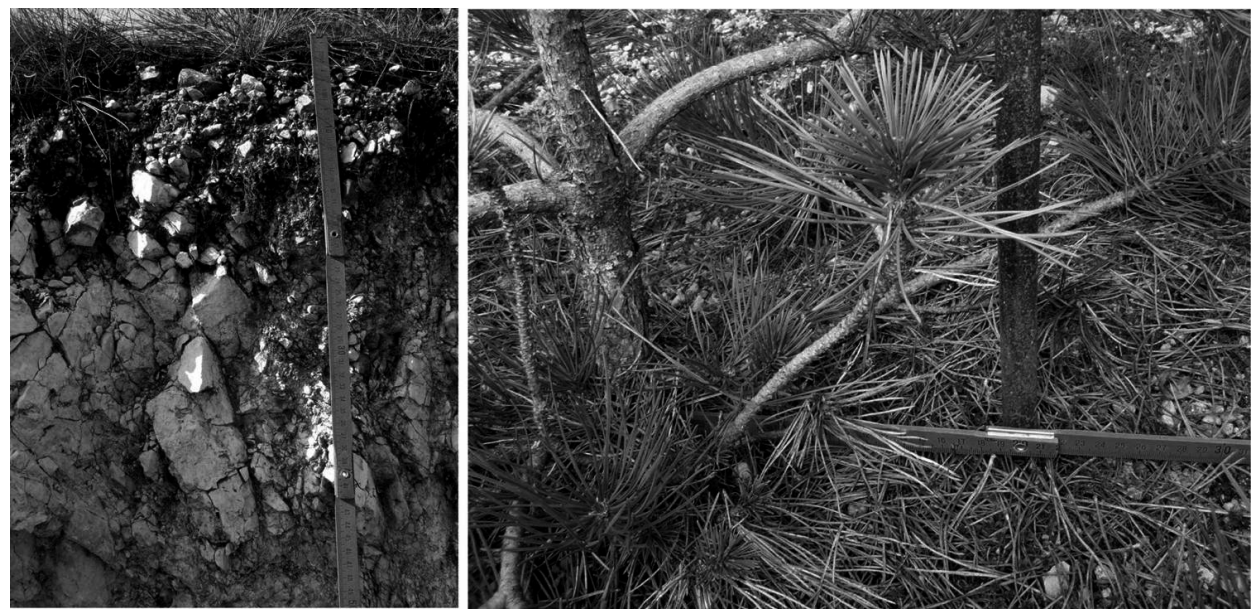

Fig. 4. Typical section of the dolomite-based skeletal soil in the studied area (Fig. 3, left) and the measuring method of soil depth in the field between a chlorotic individual (Fig. 3, right)

open area. The trunk diameter was measured at the basis of the trunk at soil level by calliper. The heights of the individuals were measured from the soil level to the top of the trunk. The diameter of the crown width diameter were calculated by the averaging of two, perpendicular measurements of the widest, lowest branches of the pines.

We determined the segment as the annual vertical and radial internodes between the branching levels of two adjacent years (Fig. 5). The vertical dimension of a segment was measured between the two adjacent levels, the diameter of the segment was measured at the half of the segment.

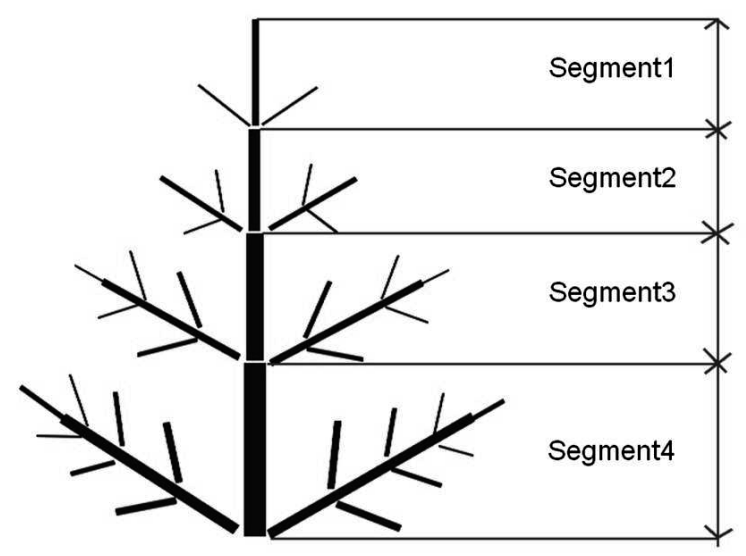

Fig. 5. Schematic illustration of the segment definition 
Growth ratio - The growth ratio of a year $\left(G R_{n}\right)$ was defined as the proportion of the growth in the current and the previous year to avoid the possible long-term changing trend of the growing of the young individuals and the accidental secondary effect of shoot (Eq.1). This calculation was based on the different aged population of the Site-3's individuals.

$$
\text { Eq.1: } G R_{\mathrm{n}}=h_{\mathrm{n}} / h_{\mathrm{n}-1}
$$

Climate data - We used the MPI Echam5 climate model (Jungclaus et al. 2006), which was based on the SRES A1B scenario (Gaffin et al. 2004, Nakicenovic et al. 2000) of the period of January 2081 to December 2100 from the ENSEMBLES homepage (Van der Linden and Mitchell 2009). The monthly mean of daily air temperature and the monthly sum of daily precipitation data of the observed and the predicted periods were acquired from the $(\mathrm{E}$ OBS 2014) with $0.25^{\circ}$ grid resolution. The latitudinal expansion was $46.632^{\circ}-$ $48.496^{\circ} \mathrm{N}$, while the longitudinal was $17.813^{\circ}-19.688^{\circ}$. Due to the different grids the model and the E-OBS dataset use, there is a slight difference in the domains we acquired the data from. The latitudinal domain was $47.00^{\circ}-47.50^{\circ}$ $\mathrm{N}$, while the longitudinal was $17.755^{\circ}-18.25^{\circ} \mathrm{E}$ in case of the observed data $\mathrm{E}$ in case of predicted data. For calculating the climatic requirements of the species within its natural distribution the climatic data (monthly precipitation sum and monthly mean temperature) of the period 1961-1990 were gained from the REMO European regional climate model (RCM). The grid had a 25 $\mathrm{km}$ horizontal resolution.

The used aridity index - We used the Thornthwaite Agrometeorological Index (Thornthwaite 1948; Eq.2) as aridity index (Kemp 1990); we averaged the monthly values during the calculation of the correlations and the modelling steps. The dimension of TAI is $\mathrm{mm} /{ }^{\circ} \mathrm{C}$. Studying the aridity within the natural distribution of $P$. nigra (histogram and descriptive statistics) we calculated the monthly TAI for each grid cells were calculated by ESRI ArcGIS 10.0 software using REMO model.

$$
\text { Eq.2: } T A I=1.65 \times(P /(T+12.2))^{10 / 9}
$$

Finding correlation between the aridity index and the standardised growth ratio - We studied the association between the mean of the TAI of the months for continuous periods within the vegetation season of the year and the annual growth ratio. Continuous periods of the aridity indices of 9th, 10th, 11th and 12th months of the previous year also were involved in the study. The correlation with the best fitted significance value and R2 of the options was chosen. We used this simple method to avoid the collinearity due to the few numbers (11) of the testable years and the relatively large number of the variables (12-14). We used the equation of the best fit linear regression correlation as the model of the aridity-based annual growing model of the species. 
The years of 2004 to 2013 were used as the reference period.

The natural distribution data of Pinus nigra - The current (latest update was achieved in 2011) continuous distribution map of the species Pinus nigra was derived from the EUFORGEN digital area database (Euforgen 2014), while the discrete (fragmented) observations were ignored.

The growth model - Due to the relativity in the GR definition, the absolute annual segment growth is the function of the starting height. The planting size of the trees was about $10 \mathrm{~cm}$. We calculated the annual segment growth of the individuals using the gained coefficients of linear regression between the TAI values of the adequate period of the year and the measured GRs. We used the equation of the continuous interval of the year which gave the best regression. According to the mean planting size of the seedlings we used 10 $\mathrm{cm}$ total vertical growth as the starting size of the planted individuals. The total heights of Austrian pines in case of a specific age of the individuals were estimated as the sum of the iteratively calculated annual segment growths of the years (Eq.3) plus the initial $10 \mathrm{~cm}$ mean size of the seedlings.

$$
\begin{gathered}
\text { Eq.3: } h_{\mathrm{n}}=h_{\mathrm{n}-1} \times G R_{\mathrm{n}} \\
h=10+\sum h_{\mathrm{n}}
\end{gathered}
$$

The estimation of the growth model provided a maximum total height according to the aridity values of the studied period starting from the height of $10 \mathrm{~cm}$ (Eq.4).

$$
\text { Eq.4: } r=h m_{\mathrm{n}} / h c_{\mathrm{n}}
$$

Modelling the influence of the soil depth on the growth of the individuals - We used the correlation between soil thickness and the total height of the similarly old individuals as the main factor, which determines the absolute height of the individuals. Due to the permanency of the soil thickness in case of young individuals the soil thickness has no influence on the deviation of the individual trends (Cseresnyés et al. 2006). According to the plantation of same aged individuals of the Site- 1 and Site- 2 we calculated the correlation between the proportion of the measured and the calculated (estimated) annual vertical growth values and the soil depth values. The annual vertical growth was calculated in different soil depths according to the Eq.5.

$$
\text { Eq.5: } h m_{\mathrm{n}}=r \times h c_{\mathrm{n}}
$$

Morphometrics - We modelled the volume of the trunk with the volume of a conic:

$$
\text { Eq.6: } v=1 / 3 \times A_{\mathrm{b}} \times h c_{\mathrm{n}}
$$


The surface area of a pine canopy was calculated according to Burkhart and Tomé (2012; Eq.7). Due to the young age of the individuals we postulated that the foliated crown height is equal to the total height of the individual.

$$
\text { Eq.7: } A c=\frac{\pi \cdot c w}{2} \pm \sqrt{(c l)^{2}+\left(\frac{c w}{2}\right)^{2}}
$$

Aridity within the distribution of Pinus nigra - It was hypothetised that the distribution of Pinus nigra can be determined by the seasonal aridity patterns in the species' natural area which can be compared to field results. Monthly Thornthwaite's Agrometeorological Indices (TAI; Kemp 1990) for each grid cell and histogram and descriptive statistics of TAI within the distribution of Pinus nigra were calculated by ESRI ArcGIS 10.0 software after an Inverse Distance Weighted (IDW) interpolation of TAI with 12 variable neighbouring points and second power (Fig. 6).



Fig. 6. Averaged TAI of the month April in the period 1961-1990 
Abbreviations used - TAI $=$ Thornthwaite Agrometeorological Index; TAIm $=$ the mean of Thornthwaite Agrometeorological Index of different periods of the year; $G R n=$ annual vertical growth ratio of the $n$th year; $h n=$ the absolute vertical growth of a year; $h n-1=$ the absolute vertical growth of a previous year; $h m n=$ the measured total height of the $n$th years old tree; $h c n=$ calculated: the calculated (estimated) total height of the $n$th years old tree; $P=$ monthly sum of precipitation $[\mathrm{mm}] ; T=$ monthly mean temperature $\left[{ }^{\circ} \mathrm{C}\right] ; v=$ the volume of the trunk; $A b=$ the basal area of the trunk; $A c=$ the surface area of a pine canopy; $d s=$ diameter of the trunk at soil level; $c w=$ diameter at the canopy at the base $(\mathrm{cm}) ; \mathrm{cl}=$ foliated crown height $(\mathrm{cm}) ; r=$ the growth-soil depth coefficient; $m s=$ mean soil depth.

\section{RESULTS}

\section{Aridity within the distribution of Pinus nigra}

Descriptive statistics and histogram of the monthly TAI values found within the distribution of the studied species are provided by Figure 7 . The minimum aridity values showed similar annual run: from the period of November to April this value was constantly above 1.0 and reached the 0 value in July and August. The 1st-Quartile values showed very similar annual run (Fig. 7). In the colder period of the year the kurtosis and the skewness of the curves have higher values than in the summer period, which may refer to the fact, that the TAI and consequently the wetness of a season in the native distribution of Pinus nigra is more decisive in the colder and cool than in the dryer and warm seasons. In contrast, despite the aridity of the late autumn, the winter and the early spring determine rather the native occurrence, the median of

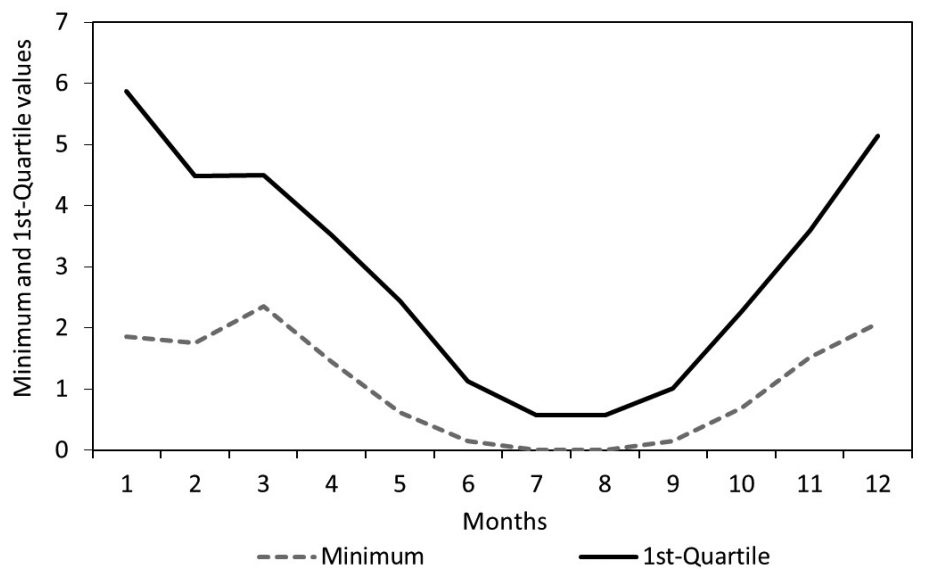

Fig. 7. The annual run of the minimum and the 1st-Quartile values of monthly TAI found the distribution of the studied species 
TAI values is more close to the lower values than in case of the warmer seasons, which may mean that in the more marginal areas of the distribution the winter precipitation is an important determinant of the vitality of the individuals (Fig. 8).

\section{Morphometric correlations}

We found significant correlation $\left(\mathrm{R}^{2}=0.66, \mathrm{p}<0.001\right)$ between the diameter of the trunk at the soil level $\left(c_{w}\right)$ and the vertical height (Eq.8: $R^{2}=0.66$; Fig. 9, left). We also found significant correlation $(\mathrm{p}<0.001)$ between the height of the tree $(h)$ and the width of the lowest crown width (Eq.9: $\mathrm{R}^{2}=0.93$; Fig. 9, right).

$$
\begin{aligned}
& \text { Eq.8: } d_{\mathrm{s}}=0.0229 h+1.3405 \\
& \text { Eq.9: } c_{\mathrm{w}}=0.6684 h+10.1679
\end{aligned}
$$

The correlation between the tree size and soil depth - We found significant correlation $(p<0.001)$ between height and the soil depth $\left(\right.$ Eq.10: $R^{2}=0.67$, $\mathrm{p}<0.001$; Fig. 10, left) in case of Site-1. We also found significant correlation $(\mathrm{p}<0.001)$ between height and the mean soil depth $\left(\right.$ Eq.11: $\mathrm{R}^{2}=0.67, \mathrm{p}<0.001$, Fig. 10, right) in case of Site-2. The correlation of the soil depth data and the corresponding height data of the Pinus nigra individuals Site- 1 and Site- 2 show a significant correlation as the basis data (Eq.12: $\mathrm{p}<0.001, \mathrm{R}^{2}=0.54$ ).

$$
\begin{gathered}
\text { Eq.10: } h m_{\mathrm{n}}=22.5472 m s+46.5705 \\
\text { Eq.11: } h m_{\mathrm{n}}=17.9778 m s+7.0636 \\
\text { Eq.12: } h m_{\mathrm{n}}=20.0345 m s+24.3157 \\
\text { Eq.13: } d s=0.9857 m s-1.5032 \\
\text { Eq.14: } d s=0.5123 m s+0.5251
\end{gathered}
$$

We found significant correlation $(\mathrm{p}<0.001)$ between the diameter of the trunk at the soil level and the soil depth (Eq.13: $R^{2}=0.59$; Fig. 11, left) in case of Site-1. We also found significant correlation $(\mathrm{p}<0.001)$ between the diameter of trunk at the soil level and the soil depth (Eq.14: $R^{2}=0.45$; Fig. 11, right) in case of Site- 2 .

The correlation between the growth ratio and the aridity - We found significant correlations in the period of 2003 to 2013 between the averaged TAI of the same year from January to May (Eq.15: $\mathrm{R}^{2}=0.62$, $\mathrm{p}<0.01 ;$ Fig. 12, in February to June (Eq.16: $\mathrm{R}^{2}=0.57, \mathrm{p}<0.01$; Fig. 12) and in February to May (Eq.17: $\mathrm{r}^{2}=$ $0.54, \mathrm{p}<0.01$; Fig. 12). We used the equation (Eq.15) of the correlation with the strongest $\mathrm{R}^{2}$ in the climate modelling.

$$
\text { Eq.15: } h_{\mathrm{n}}=0.1068 \times \operatorname{avg}_{\mathrm{m} \varepsilon[1,5]} \mathrm{TAI}_{\mathrm{m}}+0.8601
$$




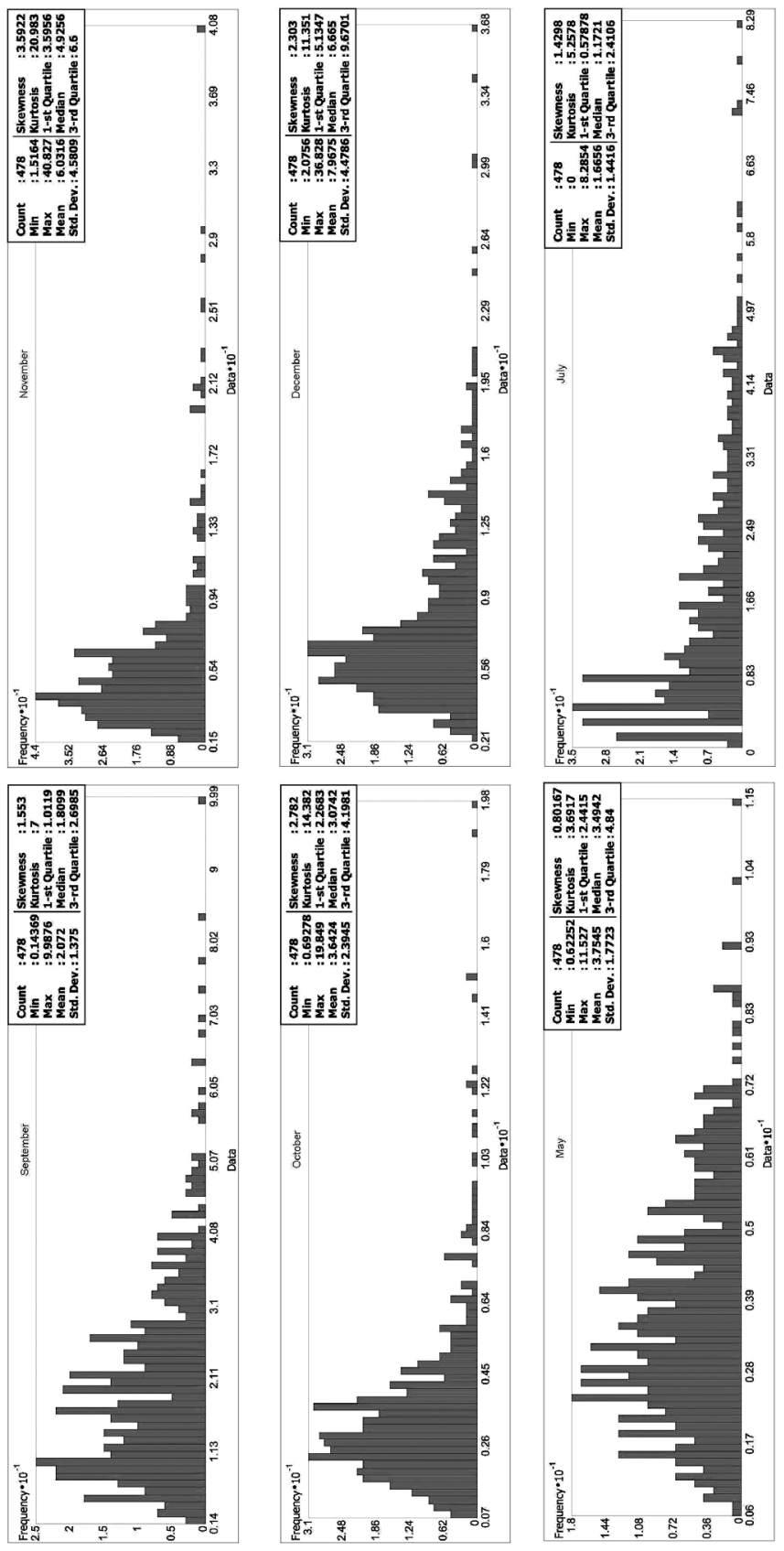

Fig. 8. Descriptive statistics and histogram of the monthly TAI values found within the distribution of the studied species 


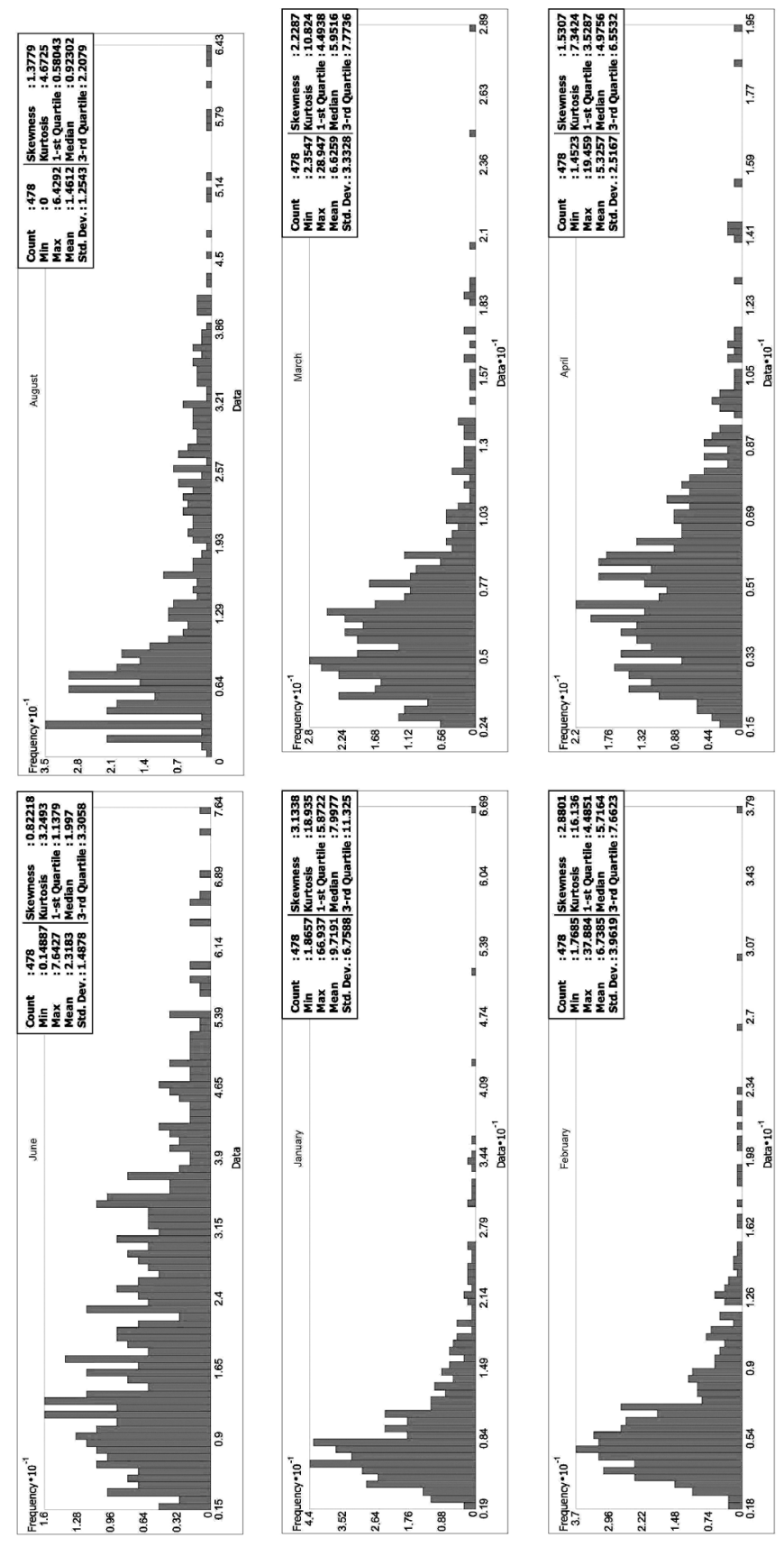

Fig. 8. (continued) 

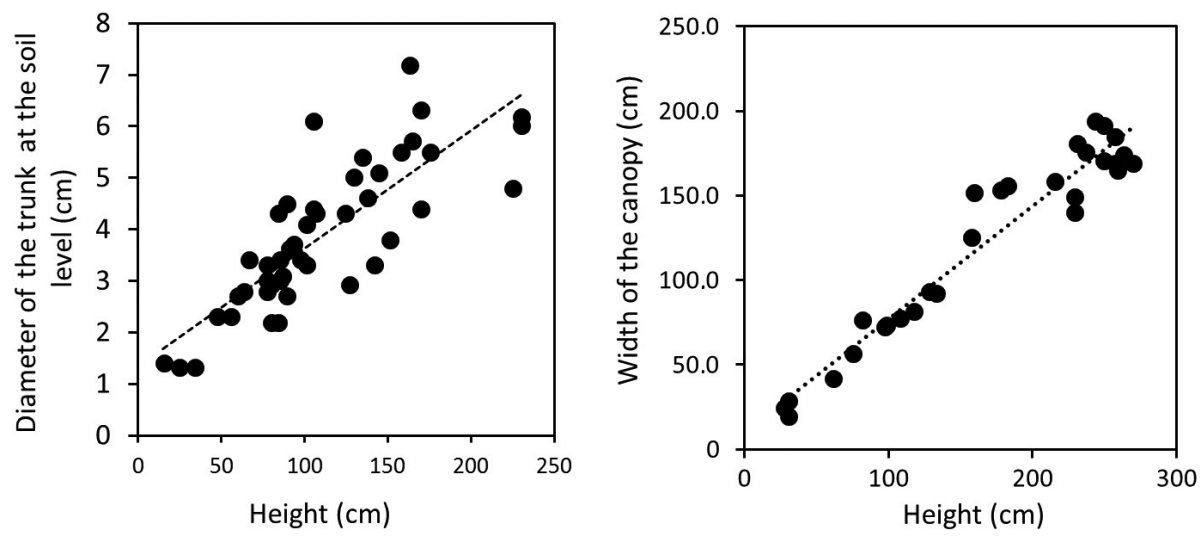

Fig. 9. The correlation between the vertical height and the diameter of the trunk at soil level

(left graph) and the correlation of the height and the crown diameter (right graph)

$$
\begin{aligned}
& \text { Eq.16: } h_{\mathrm{n}}=0.1151 \times \operatorname{avg}_{\mathrm{m} \varepsilon[2,6]} \mathrm{TAI}_{\mathrm{m}}+0.8282 \\
& \text { Eq.17: } h_{\mathrm{n}}=0.1032 \times \operatorname{avg}_{\mathrm{m} \varepsilon[2,5]} \mathrm{TAI}_{\mathrm{m}}+0.8332
\end{aligned}
$$

\section{The model results}

The correlation between the measured and the calculated heights - Since the heterogenic aged, but young pine population of Site-3 provided the determination of correlation between the annual stem growth and aridity, using the Eq.15 we can model the potential height of the pine individuals of Site-1 and Site-2 according to the reference population of Site-3. As the maximum soil
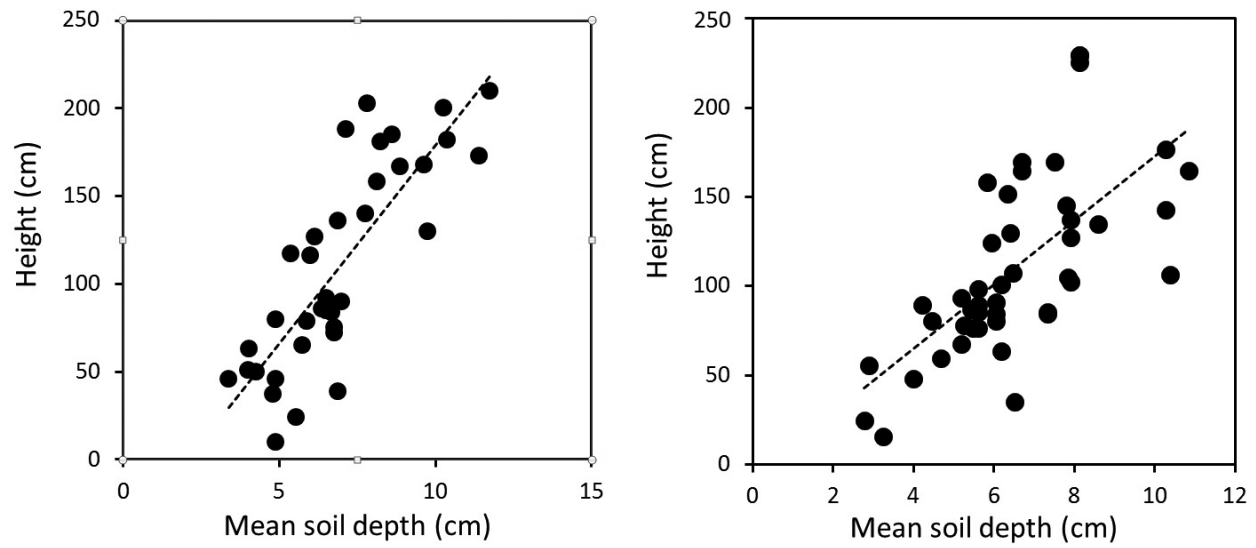

Fig. 10. The correlation between the vertical height and the soil depth of 6 years old individuals in Site-1 (left graph) and in Site-2 (right graph) 

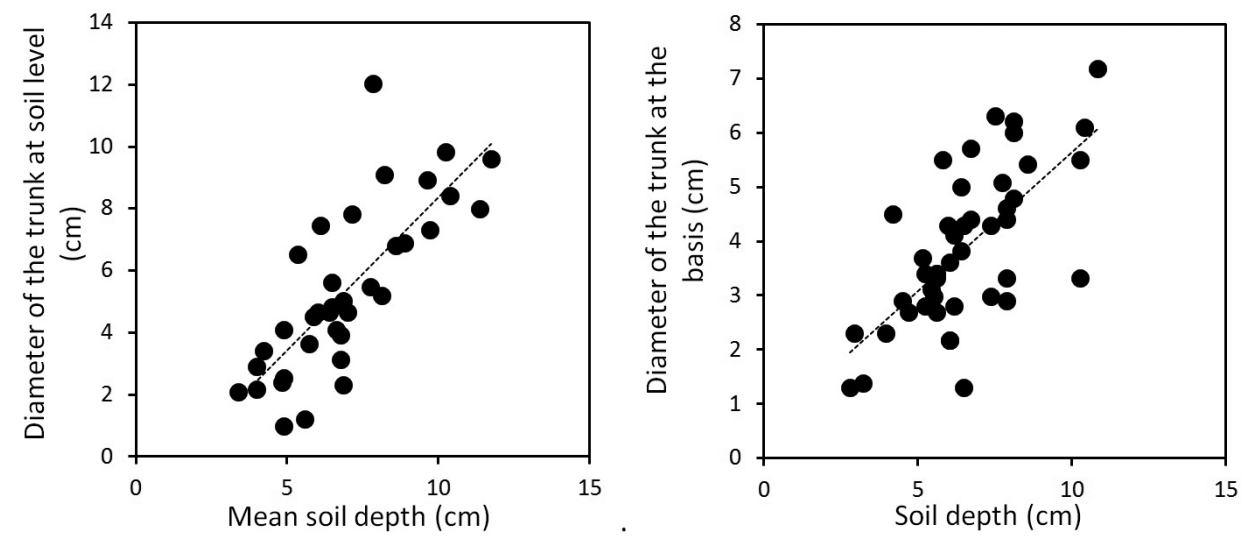

Fig. 11. The correlation between the diameter of the trunk at the soil level and the soil depth in Site-1 (left graph) and the correlation between the diameter of the trunk at the soil level and the soil depth in Site-2 (right graph)

thickness in the studied sites were of 0 (practically from $2 \mathrm{~cm}$ ) to $11 \mathrm{~cm}$ we can determine the influence of the soil thickness on the total growth which is independent from the age of the individuals or the aridity indices. According to the maximum soil thickness of the sites, the thickness of $11 \mathrm{~cm}$ occurred as the reference. We determined the correlation between the ratio of the measured and calculated heights of the Pinus nigra individuals based on the initial height of $10 \mathrm{~cm}$ according to the Eq.15 and based on the real aridity indices of the period under the growth of the individuals $\left(n=81, R^{2}=0.54\right.$, Eq.18).

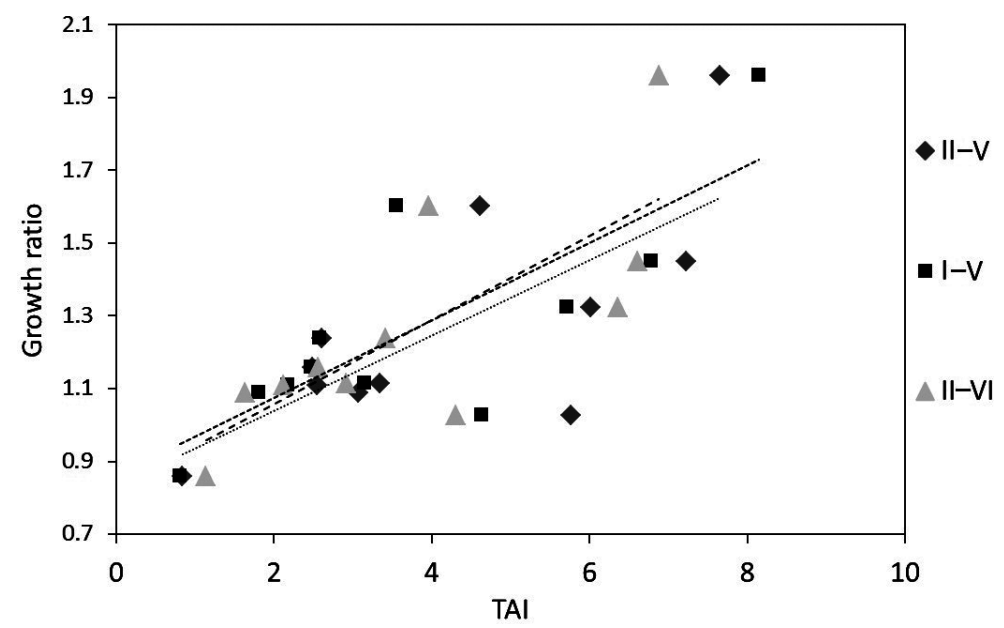

Fig. 12. Correlations between the growing ratios of the annual segments and the annual averages of the monthly TAI values. Black square: from January to May, dark grey rhombus: from February to May, light grey triangle: from February to June 

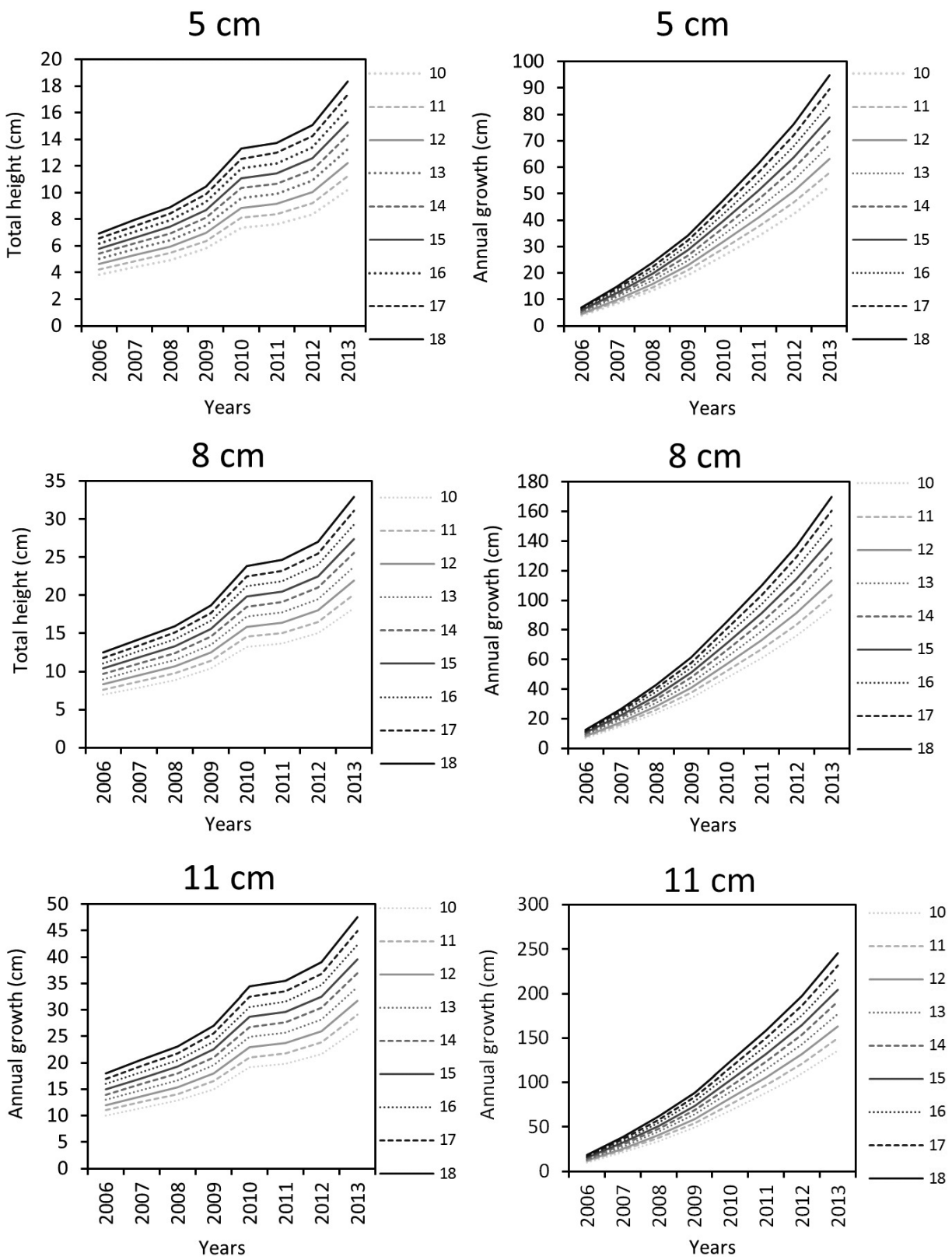

Fig. 13. The modelled runs of the annual growth in case of different initial heights and soil depth conditions $(5,8$ and $11 \mathrm{~cm}$ according to the Chart title) of the seedlings in the model in the period of 2006 to 2013 at $10 \mathrm{~cm}$ soil depth and the modelled height of the seedlings in case of different initial heights in the period of 2006 to 2013 at $10 \mathrm{~cm}$ soil depth 
The gained Eq.18 hereinafter was used as to calculate the aridity-independent multiplying factor of soil thickness to determine the predicted real height of the given aged individuals (Fig. 14).

$$
\text { Eq.18: } h m_{\mathrm{n}}=0.1020 h c_{\mathrm{n}}+0.1238
$$

The modelled maximum growth of $P$. nigra with different initial heights - The output of the model is influenced by the initial size of the planted individuals (Fig. 13, left). Calculating with the TAI indices of the period of 2006-2013 the model returned 168.2 (initial size: $10 \mathrm{~cm}$ ) to $252.4 \mathrm{~cm}$, initial size: $10 \mathrm{~cm}$ (Fig. 13, right). In case of $5 \mathrm{~cm}$ the modelled total height of from the initial height of $10 \mathrm{~cm}$ is 10.20; from the initial height of $18 \mathrm{~cm}$ is modelled to $18.36 \mathrm{~cm}$. The total height in the end of the 8 years period between the initial heights of 10 $\mathrm{cm}$ is $52.62 \mathrm{~cm}$, in case of $18 \mathrm{~cm}$ is projected to be $94.71 \mathrm{~cm}$. In case of $8 \mathrm{~cm}$ the modelled total height of from the initial height of $10 \mathrm{~cm}$ is $18.28 \mathrm{~cm}$; from the initial height of $18 \mathrm{~cm}$ modelled to $32.91 \mathrm{~cm}$. The total height in the end of the 8 years period between the initial heights of $10 \mathrm{~cm}$ is $94.31 \mathrm{~cm}$, in case of $18 \mathrm{~cm}$ is projected to be $169.76 \mathrm{~cm}$. In case of $8 \mathrm{~cm}$ the modelled total height of from the initial height of $10 \mathrm{~cm}$ is $26.41 \mathrm{~cm}$; from the initial height of $18 \mathrm{~cm}$ modelled to $47.54 \mathrm{~cm}$. The total height in the end of the 8 years period between the initial heights of $10 \mathrm{~cm}$ is $136.25 \mathrm{~cm}$, in case of $18 \mathrm{~cm}$ is projected to be 245.25 $\mathrm{cm}$. The modelled growth trend of the pines showed increase between the 2009 and 2010 due to the anomalously wet year of 2010, while between 2010

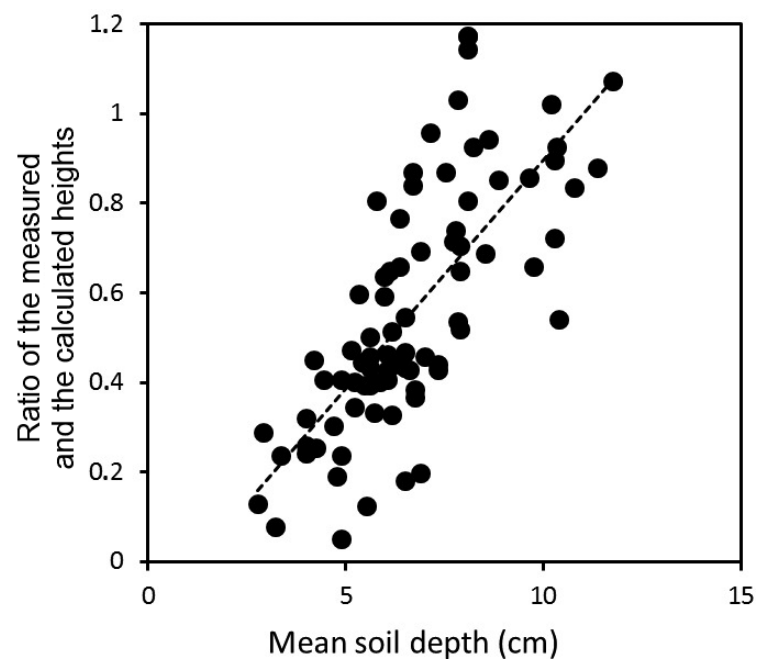

Fig. 14. The correlation between the ratio of the measured and calculated heights of the Pinus nigra individuals 


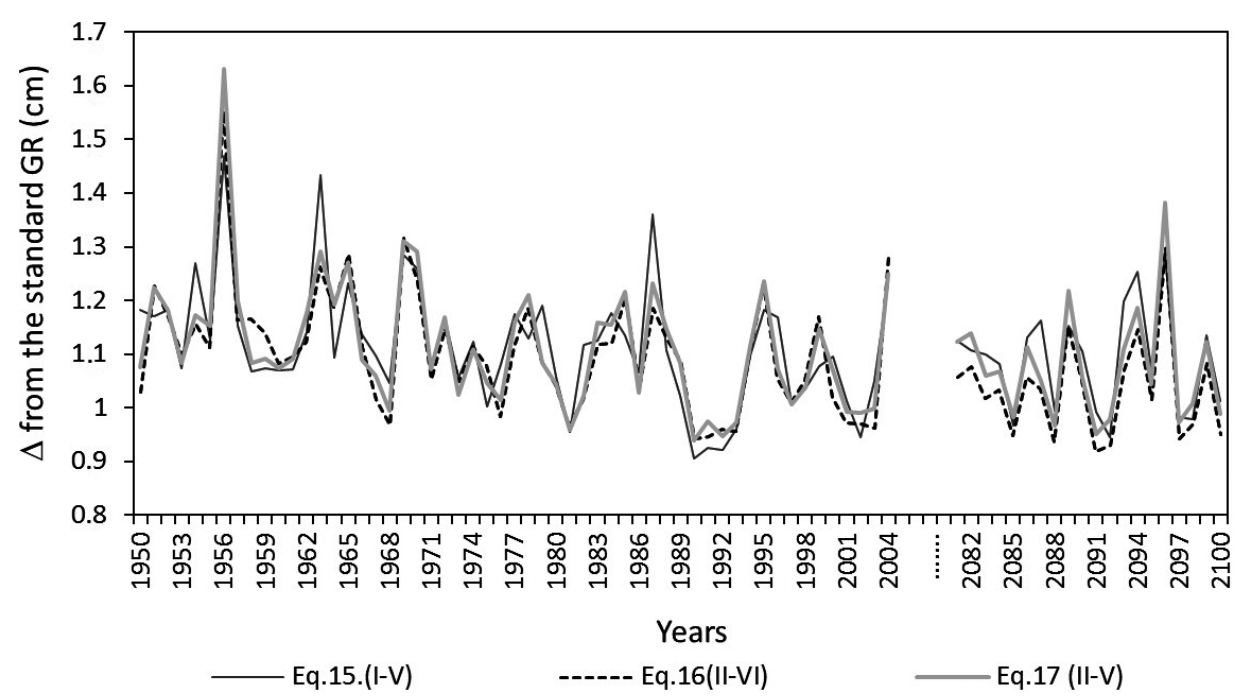

Fig. 15. The modelled difference values of the annual growing of Pinus nigra, from the reference period 2004-2013 (using Eq.15, Eq.16 and Eq.17)

and 2011 due to the anomalously dry period the modelled growth trend of the pines showed a marked decrease.

The modelled heights of $\mathrm{P}$. nigra on different soil depths from the period of 19502003 and 2081-2100 - Our model outcome predicted a significant decreasing trend in case of Eq.15 $(\mathrm{p}<0.05)$ and Eq.16 $(\mathrm{p}<0.05)$ and non-significant trend in case of Eq.17 ( $\mathrm{p}=0.0896)$ of the vertical growing of $P$. nigra from the period of 1950-2003 and 2081-2100. The three models gave similar outcomes (Eq.15 and Eq.16: $\mathrm{R}^{2}=0.96$, and Eq.15 and Eq.17: $\mathrm{R}^{2}=0.94$; Fig. 15). Relatively low values can be seen in 1958-1962, 1990-1993. Note that in 1960-1962, 1992 and 1993 major forest decays occurred in the Transdanubian Mountain Range (Koltay 2001a).

While the modelled morphometric values of Pinus nigra individuals (according to the initial height of $10 \mathrm{~cm}$ ) show a marked decrease between the periods of 1959-1967 and 1995-2003, however between the periods of 1995-2003 and 2090-2097 the difference is low or negligible; the differences are more pronounced in case of thicker soils: the modelled height in case of $2 \mathrm{~cm}$ soil depth in 1959-1967 is $24.24 \mathrm{~cm}$, in 1995-2003 is $15.20 \mathrm{~cm}$, in 2090-2097 is 15.20 $\mathrm{cm}$, while in case of $11 \mathrm{~cm}$ soil depth in 1959-1967 (max.) is $254.56 \mathrm{~cm}^{2}$, in 19952003 is $189.28 \mathrm{~cm}^{2}$, in $2090-2097$ is $189.28 \mathrm{~cm}^{2}$. The modelled canopy width in case of $2 \mathrm{~cm}$ soil depth in 1959-1967 (max.) is $26.37 \mathrm{~cm}$, in 1995-2003 is 26.37 $\mathrm{cm}$, for 2090-2097 is $20.33 \mathrm{~cm}$, while the modelled canopy width in case of $11 \mathrm{~cm}$ soil depth in 1959-1967 is $211.86 \mathrm{~cm}, 1995-2003: 136.68 \mathrm{~cm}, 2090-2097$ : 
$136.68 \mathrm{~cm}$. The modelled trunk volume in case of $2 \mathrm{~cm}$ soil depth in 1959-1967 is $22.79 \mathrm{~cm}^{3}$, in $1995-2003$ is $11.34 \mathrm{~cm}^{3}$, in $2090-2097: 11.34 \mathrm{~cm}^{3}$, while in case of $11 \mathrm{~cm}$ soil depth in 1959-1967 (max.) is $3424.58 \mathrm{~cm}^{3}$, in 1995-2003 is 1,595.12 $\mathrm{cm}^{3}$ in 2090-2097 is $1,595.12 \mathrm{~cm}^{3}$ (left) and the modelled canopy surface in case of $2 \mathrm{~cm}$ soil depth in 1959-1967 is $61.09 \mathrm{~cm}^{2}$, in 1995-2003 is $50.21 \mathrm{~cm}^{2}$, $2090-2097$ is $50.21 \mathrm{~cm}^{2}$, while in case of $11 \mathrm{~cm}^{2}$ soil depth in 1959-1967 is 553.16 $\mathrm{cm}^{2}, 1995-2003$ is $415.83 \mathrm{~cm}^{2}, 2090-2097$ is $415.83 \mathrm{~cm}^{2}$ (right).
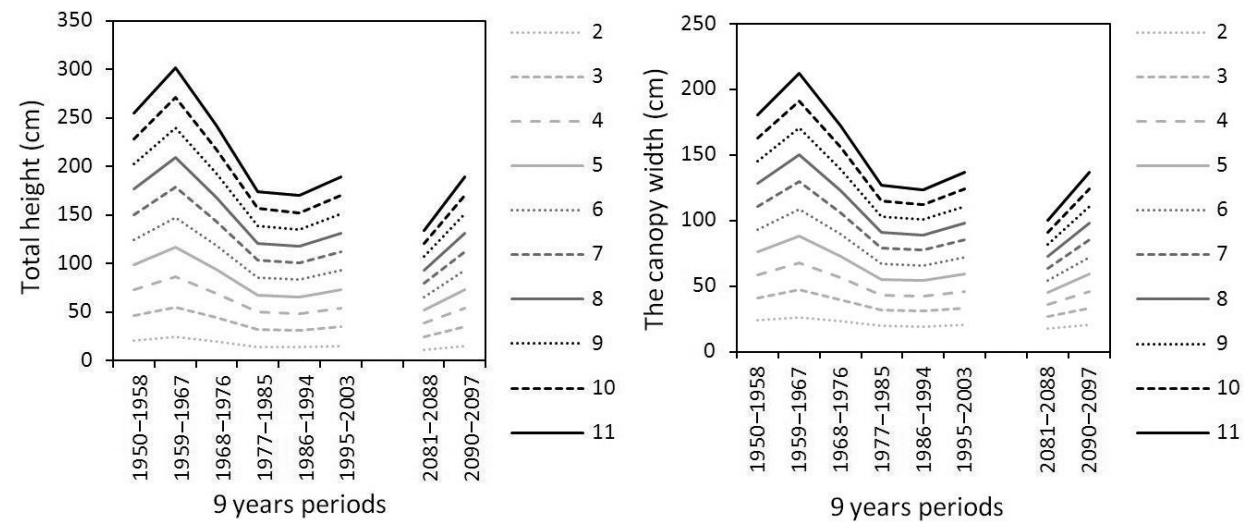

Fig. 16. The modelled height (in $\mathrm{cm}$ ) of nine years old seedlings on different soil depths calculated for 9 years periods of the past and the modelled future according to the Eq.11 (left) and the modelled canopy width (in $\mathrm{cm}$ ) of nine years old seedlings on different soil depths calculated for 9 years periods of the past and the modelled future according to the Eq.11 (right)
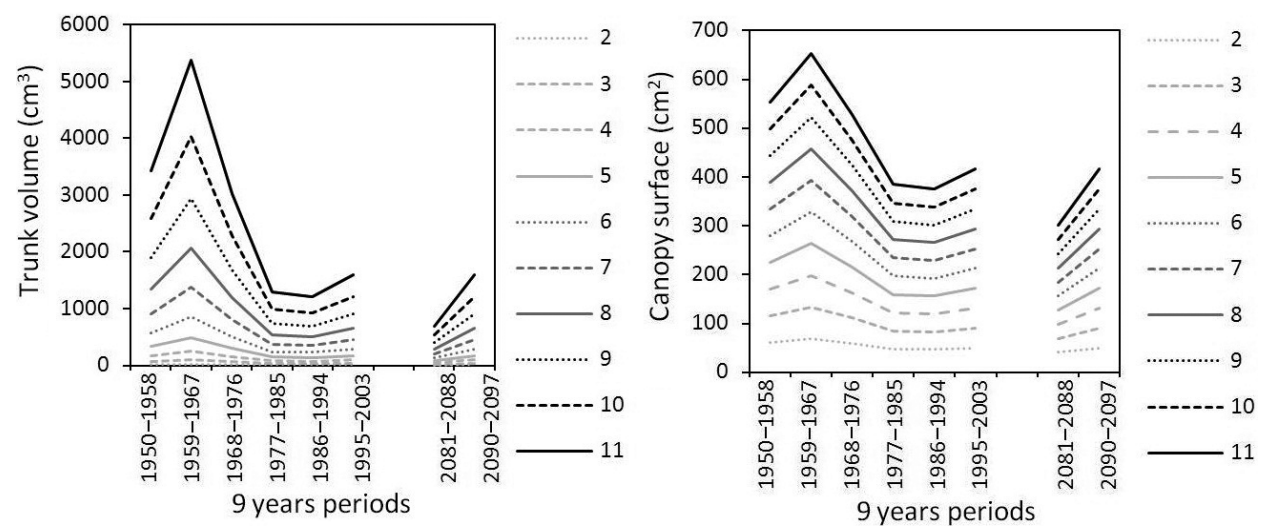

Fig. 17. The modelled volume of the trunk volume $\left(\mathrm{cm}^{3}\right)$ of nine years old seedlings on different soil depths calculated for 9 years periods of the past and the modelled future according to the Eq.15 (left) and the modelled surface area of the canopy $\left(\mathrm{cm}^{2}\right)$ of nine years old seedlings on different soil depths calculated for 9 years periods of the past and the modelled future according to the Eq.15 (right) 


\section{DISCUSSION}

A major benefit of the model results is that the retrospective modelling coincided with the increasing frequency of the Pinus nigra forest decays in the last two decades. The model results showed the best growth conditions for the 1950s, 1960s and 1970s when only 3 forest decay years occurred, while from the 1980s the start of the accelerating recent climate change the model returned the rapid decrease of the morphometric values and consequently the vitality patterns of the species and 14 years occurred with major Pinus nigra forest decay only in the last 3 decades and 2 in 2010-2012 in Hungary according to the assessment report of Koltay (2001a). The temperature anomalies of the Northern Hemisphere showed a continuously increasing trend from the 1980s, according to the mean of the last 1.5 hundred years (Jones et al. 2006) and the temperature trends from 1980 to 2008 exceeded one standard deviation of historic year-toyear variability (Lobell et al. 2011). According to the used climate projections, a similar frequency of the $P$. nigra forest decay expected for the last two decades of the 20th century in Hungary as it was observed in the last two decades. These results reflect the observations that tree populations at the rear edge of the natural distribution are sensitive to climate stress and drought (Camarero et al. 2013). Our results indicate that though P. nigra can grow on thin, carbonate-rich soils from $2 \mathrm{~cm}$ of mean soil level, the growing rate of $P$. nigra showed strong correlation with soil depth. These observations are consistent with the findings of Sabaté et al. (2002) who described that access of roots to deeper soil in case of Pinus species has a positive effect on final wood yield due to the improved water uptake. We also demonstrated that the annual growth of $P$. nigra is highly tolerant to the summer aridity. Since climate scenarios project increasing summer aridity and increasing autumn-winter precipitation trend in Hungary it is plausible that the dryer and hotter summers will not influence negatively the growing parameters of $P$. nigra. However, dry and hot summers can negatively effect the survival due to e.g. fungal infections as the Diplodia shoot disease in Hungary (Igmándy and Pagony 1988) or the recurring of wildfires (Espelta et al. 2003). Linares and Tíscar (2010) also confirmed that $P$. nigra is able to adapt to increased extreme events such as prolonged droughts. Our observations showed that $P$. nigra was sensitive to the aridity of the period of January to May (or even to June). Although the results of the aridity analysis we achieved within the distribution of $P$. nigra indicated the influence of the previous year's precipitation to the present year's growing rate, our field study did not confirmed the importance of the wetness of the complete cold season in case of the studied population. Our analysis found the importance of the second part of the winter and the spring precipitation on the growth of $P$. nigra. It is plausible that in case of the studied extreme thin soils on karstic bedrock this effect can be insignificant due to the low water storage capacity. Naturally, our conception 
was not built on the continuous growth of the individuals, but it is plausible that the higher soil moisture in late winter and early spring may have positive influence on the later spring growing of the Austrian pine. Our observations are comparable to the results of Martín-Benito et al. (2008), who found that May is the most influential month on the growth of the early wood of $P$. nigra in Spain. Espelta et al. (2003) found that wide rings of $P$. nigra were significantly associated with high precipitation in April to June and August to September of the preceding year. These observations could be the consequence of the adaptation of the different subspecies to the different climate and the annual precipitation patterns of Iberia and Central Europe. In Austria, Leal et al. (2008) found that the width of tree rings of $P$. nigra trees, which Austrian variety, Pinus nigra var. austriaca (it is identical to the most frequently planted variety of $P$. nigra in Hungary, showed a strong positive correlation with spring-summer precipitation. It is notable that the Austrian populations of $P$. nigra live in mountainous area, where the summer is wetter than in the karst plateau of Veszprém. Our observations correspond with the fact that Mediterranean forest growth is constrained by drought and high temperatures during summer (Sabaté et al. 2002) and the ligneous plants of the Mediterranean developed to adapt to the use the precipitation of the relatively wet period of late autumn to early spring. The solution to the partial difference of the results between the natural distribution and field analysis can be the facts that the native distribution of $P$. nigra is mainly restricted to the Mediterranean region, where the annual precipitation patterns with the characteristic dry and hot summers and wet winters are completely different from the precipitation seasonality of the Carpathian Basin, where recently the winter season is relatively arid and summer is the most wet season. Furthermore, the Carpathian Basin is the most northern occurrence of the species, where the climate is not typical for the origin habitats of the species. Although our model did not contain the possible effect on growing of the increasing atmospheric carbon-dioxide content, Kaushal et al. (1989) described that the height and diameter growth of $P$. nigra were only $10 \%$ higher even in $800 \mu \mathrm{mol} \cdot \mathrm{mol}^{-1} \mathrm{CO}_{2}$ concentration in contrast of the $350 \mathrm{ppm} \mathrm{CO}_{2}$, which could not significantly influence our model. However, Sabaté et al. (2002) found that the increasing temperature and the decreasing rainfall may constrain the growth of ligneous plants during certain periods, due to the mainly winter and spring aridity sensitivity of $P$. nigra a significant negative effect of future climate (for 2081-2100) on the growth rate of this pine is not likely in young individuals. Our model results regarding to the past five decades can explain the reason why the foresters have achieved good results in the plantation of black pine in the 1950s and 1960s in Hungary. An important merit of this study is that in contrast the adequate literally data our annual growth conception was built on the non-invasive measurement of the annual segments and not the width of the tree rings, which could be very invasive and difficult in case of young individuals. 
Acknowledgements - The research was supported by the following TÁMOP projects 4.2.2. A-11/1/KONV-2012-0064, 4.2.1/B-09/1/KMR-2010-0005 and 4.2.2B-15/1/KONV-2015-0004. The ENSEMBLES data used in this work was kindly funded by the EU FP6 Integrated Project ENSEMBLES (contract number 505539). We also would like to say many thanks to András Koltay for the forest decay data and Judit Schoffhauzer for her help in field work.

\section{REFERENCES}

Balla, Z. (1988): Clockwise paleomagnetic rotations in the Alps in the light of the structural pattern of the Transdanubian Range (Hungary). - Tectonophysics 145(3): 277-292. http://dx.doi.org/10.1016/0040-1951(88)90200-4

Balog, A., Haas, J., Read, J. F. and Coruh, C. (1997): Shallow marine record of orbitally forced cyclicity in a Late Triassic carbonate platform, Hungary. - J. Sedim. Res. 67(4): 661-676.

Barnes, I., Kirisits, T., Wingfield, M. J. and Wingfield, B. D. (2011): Needle blight of pine caused by two species of Dothistroma in Hungary. - Forest Pathol. 41(5): 361-369. http://dx.doi.org/10.1111/j.1439-0329.2010.00689.x

Blodgett, J. T. and Stanosz, G. R. (1997): Sphaeropsis sapinea morphotypes differ in aggressiveness, but both infect nonwounded red or jack pines. - Plant Disease 81(2): 143-147. http://dx.doi.org/10.1094/PDIS.1997.81.2.143

Burkhart, H. E. and Tomé, M. (2012): Modeling forest trees and stands. - Springer, 457 pp. http://dx.doi.org/10.1007/978-90-481-3170-9

Camarero, J. J., Manzanedo, R. D., Sanchez-Salguero, R. and Navarro-Cerrillo, R. M. (2013): Growth response to climate and drought change along an aridity gradient in the southernmost Pinus nigra relict forests. - Ann. Forest Sci. 70(8): 769-780. http://dx.doi. org/10.1007/s13595-013-0321-9

Cseresnyés, I., Csontos, P. and Bózsing, E. (2006): Stand age influence on litter mass of Pinus nigra plantations on dolomite hills in Hungary. - Can. J. Bot. 84(3): 363-370. http://dx.doi.org/10.1139/b06-003

Csillag, V. (2006): Feketefenyő-pusztulás a Keszthelyi-hegységben. - Erd. Lapok 141: 279-280.

Csontos, P., Horánszky, A., Kalapos, T. and Lőkös, L. (1996): Seed bank of Pinus nigra plantations in dolomite rock grassland habitats, and its implications for restoring of the grassland vegetation. - Annls hist.-nat. Mus. natn. hung. 88: 69-78.

Espelta, J. M., Retana, J. and Habrouk, A. (2003): An economic and ecological multi-criteria evaluation of reforestation methods to recover burned Pinus nigra forests in NE Spain. - Forest Ecol. Manag. 180(1): 185-198. http://dx.doi.org/10.1016/S0378-1127(02)00599-6

Euforgen (2014): Distribution map of black pine (Pinus nigra). - Bioversity International, Rome, Italy. Online: www.euforgen.org [last accessed: 22.02.2014]

Ferrio, J. P. and Voltas, J. (2005): Carbon and oxygen isotope ratios in wood constituents of Pinus halepensis as indicators of precipitation, temperature and vapour pressure deficit. - Tellus B 57(2): 164-173. http://dx.doi.org/10.1111/j.1600-0889.2005.00137.x

Gaffin, S. R., Rosenzweig, C., Xing, X. and Yetman, G. (2004): Downscaling and geo-spatial gridding of socio-economic projections from the IPCC Special Report on Emissions Scenarios (SRES). - Global Env. Change 14(2): 105-123. http://dx.doi.org/10.1016/j. gloenvcha.2004.02.004

Gagen, M., McCarroll, D. and Edouard, J. L. (2004): Latewood width, maximum density, and stable carbon isotope ratios of pine as climate indicators in a dry subalpine en- 
vironment, French Alps. - Arctic, Antarctic, Alpine Res. 36(2): 166-171. http://dx.doi. org/10.1657/1523-0430(2004)036[0166:LWMDAS]2.0.CO;2

Granier, A., Reichstein, M., Breda, N., Janssens, I. A., Falge, E., Ciais, P., Grünwald, T., Aubinet, M., Berbigier, P., Bernhofer, C., Buchmann, N., Facini, O., Grassi, G., Heinesch, B., Ilvesniemi, H., Keronen, P., Knohl, A., Kostner, B., Lagergren, F., Lindroth, A., Longdoz, B., Loustau, D., Mateus, J., Montagnani, L., Nys, C., Moors, E., Papale, D., Peiffer, M., Pilegaard, K.; Pita, G., Pumpanen, J., Rambal, S., Rebmann, C., Rodrigues, A., Seufert, G., Tenhunen, J., Vesala, I. and Wang, Q. (2007): Evidence for soil water control on carbon and water dynamics in European forests during the extremely dry year: 2003. - Agric. Forest Meteorol. 143: 123-145. http://dx.doi.org/10.1016/j.agrformet.2006.12.004

Haas, J. (2002): Origin and evolution of Late Triassic backplatform and intraplatform basins in the Transdanubian Range, Hungary. - Geologica Carpathica, Bratislava, 53(3): 159-178.

Haas, J. and Demény, A. (2002): Early dolomitisation of Late Triassic platform carbonates in the Transdanubian Range (Hungary) sedimentary. - Geology 151(3): 225-242. http://dx.doi.org/10.1016/S0037-0738(01)00259-7

Igmándy, Z. and Pagony, H. (1988): A fekete fenyő pusztulását okozó diplodiás-hajtásbetegség fellépése hazánkban. - Növényvédelem 24: 307-308.

Janik, G., Nagy, A., Koltay, A., Reményfy, R., Dudás, B., Lovász, Á., Hirka, A., Szőcs, L. and Csóka, Gy. (2012): Gyors, tömeges fenyő́pusztulás a Mátrafüredi Erdészet területén. - http://www.mettars.hu/wp-content/uploads/2012/09/603_JanikGergely_et_al.pdf

Jones, P. D., Parker, D. E., Osborn, T. J. and Briffa, K. R. (2006): Global and hemispheric temperature anomalies-land and marine instrumental records. - In: Trends: a compendium of data on global change. CDIAC, Oak Ridge National Laboratory, US Department of Energy, Oak Ridge, TN., USA. Http://dx.doi.org/10.3334/CDIAC/cli.002.

Jungclaus, J. H., Keenlyside, N., Botzet, M., Haak, H., Luo, J. J., Latif, M. and Roeckner, E. (2006): Ocean circulation and tropical variability in the coupled model ECHAM5/ MPI-OM. - J. Climate 19(16): 3952-3972. http://dx.doi.org/10.1175/JCLI3827.1

Kaushal, P., Guehl, J. M. and Aussenac, G. (1989): Differential growth response to atmospheric carbon dioxide enrichment in seedlings of Cedrus atlantica and Pinus nigra ssp. laricio var. corsicana. - Can. J. Forest Res. 19(11): 1351-1358. http://dx.doi. org/10.1139/x89-209

Kemp, D. (1990): Global environmental issues: a climatological approach - Routledge, London and New York, 240 pp. http://dx.doi.org/10.4324/9780203425305

Koltay, A. (1994): A környezeti tényezők hatása a feketefenyő hajtáspusztulás kialakulásában. - Erd. Kutatások 84: 157-162.

Koltay, A. (1997): Mitől vörösödnek feketefenyveseink? A hajtások és a tűelhalások leggyakoribb tünetei feketefenyő-állományokban. - Erd. Lapok 132(1): 12-13.

Koltay, A. (1998): A feketefenyő hajtáspusztulását okozó gomba, a Sphaeropsis sapinea Dyko et Sutton biológiai vizsgálati eredményei. - Erd. Kutatások 88: 251-271.

Koltay, A. (2001a): A magyarországi feketefenyő hajtáspusztulás történeti áttekintése. Erd. Kutatások 90: 247-254.

Koltay, A. (2001b): Incidence of Dothistroma septospora (Dorog.) Morlet in the Austrian pine (Pinus nigra Arn.) stands in Hungary and results of chemical control trials. Növényvédelem 37(5): 231-235.

Koltay, A., Kövics, G. J. and Dávid, I. (2005): Health condition of Hungarian forests-appearance of new disease. - In: 10. Tiszántúli Növényvédelmi Fórum, 18-20 October 2005, Debreceni Egyetem, Agrártudományi Centrum, Debrecen, pp. 130-140.

KSH (2014): http://www.ksh.hu/docs/hun/xstadat/xstadat_eves/i_ome002a.html 
Leal, S., Eamus, D., Grabner, M., Wimmer, R. and Cherubini, P. (2008): Tree rings of Pinus nigra from the Vienna basin region (Austria) show evidence of change in climatic sensitivity in the late 20th century. - Can. J. Forest Res. 38(4): 744-759. http://dx.doi.org/10.1139/X07-189

Lengyel, Gy. (1964): A feketefenyőpusztulás kérdése. - Erdő 13(3): 126-131.

Linares, J. C. and Tíscar, P. A. (2010): Climate change impacts and vulnerability of the southern populations of Pinus nigra subsp. salzmannii. - Tree Physiol. 30(7): 795-806. http://dx.doi.org/10.1093/treephys/tpq052

Linares, J. C., Camarero, J. J. and Carreira, J. A. (2009): Interacting effects of climate and forestcover changes on mortality and growth of the southernmost European fir forests. - Glob. Ecol. Biogeogr. 18: 485-497. http://dx.doi.org/10.1111/j.1466-8238.2009.00465.x

Lobell, D. B., Schlenker, W. and Costa-Roberts, J. (2011): Climate trends and global crop production since 1980. - Science 333(6042): 616-620. http://dx.doi.org/10.1126/science.1204531

Loustau, D., Bosc, A., Colin, A., Ogée, J., Davi, H., François, C., Dufrêne, E., Déqué, M., Cloppet, E., Arrouays, D., Bas, C. L., Saby, N., Pignard, G., Hamza, N., Granier, A., Bréda, N., Ciais, P., Viovy, N. and Delage, F. (2005): Modeling climate change effects on the potential production of French plains forests at the sub-regional level. - Tree Physiol. 25: 813-823. http://dx.doi.org/10.1093/treephys/25.7.813

Martín-Benito, D., Cherubini, P., del Río, M. and Cañellas, I. (2008): Growth response to climate and drought in Pinus nigra Arn. trees of different crown classes. - Trees 22(3): 363-373. http://dx.doi.org/10.1007/s00468-007-0191-6

Martínez-Vilalta, J., López, B. C., Adell, N., Badiella, L. and Ninyerola, M. (2008): Twentieth century increase of Scots pine radial growth in NE Spain shows strong climate interactions. - Glob. Change Biol. 14: 2868-2881. http://dx.doi.org/10.1111/j.1365-2486.2008.01685.x

Márton, E. and Fodor, L. (2003): Tertiary paleomagnetic results and structural analysis from the Transdanubian Range (Hungary): rotational disintegration of the Alcapa unit. Tectonophysics 363(3): 201-224. http://dx.doi.org/10.1016/S0040-1951(02)00672-8

Nakicenovic, N., Alcamo, J., Davis, G., De Vries, B., Fenhann, J., Gaffin, S., Gregory, K., Grubler, A., Jung, T. Y., Kram, T., La Rovere, E. L., Michaelis, L., Mori, S., Morita, T., Pepper, W., Pitcher, H., Price, L., Riahi, K., Roehrl, A., Rogner, H.-H., Sankovski, A., Schlesinger, M., Shukla, P., Smith, S., Swart, R., van Rooijen, S., Victor, N. and Dadi, Z. (2000): IPCC special report on emissions scenarios. - Cambridge UP, Cambridge, 599 pp.

Sabaté, S., Gracia, C. A. and Sánchez, A. (2002): Likely effects of climate change on growth of Quercus ilex, Pinus halepensis, Pinus pinaster, Pinus sylvestris and Fagus sylvatica forests in the Mediterranean region. - Forest Ecol. Manag. 162(1): 23-37. http:// dx.doi.org/10.1016/S0378-1127(02)00048-8

Szilasi, T. (2013): Feketefenyő-pusztulás a Mecseki parkerdőben. - Erd. Lapok 148(4): 106-107.

Thornthwaite, C. W. (1948): An approach toward a rational classification of climate. Geogr. Rev. 38: 55-94. http://dx.doi.org/10.2307/210739

Van der Linden, P. and Mitchell, J. E. (2009): ENSEMBLES: climate change and its impacts: summary of research and results from the ENSEMBLES project. - Met Office Hadley Centre, Exeter, UK, 160 pp.

Veress, M. (2010): Factors influencing solution in karren and on covered karst. - Hung. Geogr. Bull. 59(3): 289-306.

Vieira, J., Campelo, F. and Nabais, C. (2009): Age-dependent responses of tree-ring growth and intra-annual density fluctuations of Pinus pinaster to Mediterranean climate. Trees 23(2): 257-265. http://dx.doi.org/10.1007/s00468-008-0273-0

Wullschleger, S. D., Tschaplinski, T. J. and Norby, R. J. (2002): Plant water relations at elevated $\mathrm{CO}_{2}$ - implications for water-limited environments. - Plant Cell Environ. 25(2): 319-331. http://dx.doi.org/10.1046/j.1365-3040.2002.00796.x 